\title{
Studies on the Prediction and Development of Diabetes in Offspring of Diabetic Chinese Hamsters
}

\author{
G.C. Gerritsen, L. B. Nemdram, F.L. Schmidt and W. E. Dutin \\ Diabetes Research, The Upjohn Company, Kalamazoo, Michigan, USA
}

\begin{abstract}
Summary. Two hundred and fifty-three hamsters born between January and September 1968 have been continuously tested biweekly for urine glucose and ketones from 15 days of age through September 1969. They comprise 67 litters out of 28 females sired by 19 males from 7 inbred lines. - All 46 hamsters from two severe ketotic diabetic parents have become diabetic (consistent 4 + Tes-Tape rating). Twenty-five of the 46 have developed ketonuria (consistent 4+ Ketostix rating). - While 100\% of the litters from ketotic diabetics became diabetic within 8 months, the incidence of diabetes from ketotic diabetic to nonketotic diabetic matings was $59 \%$; ketotic diabetic to trace ghucosuric $41 \%$; and ketotic diabetic to nondiabetic $24 \%$. - Diabetes developed earlier in progeny from ketotic diabetics than in those from milder diabetics. At 3 weeks, pups from ketotic diabetics were $26 \%$ trace glucosuric, $26 \%$ diabetic, $2 \%$ ketotic and by 2 months $85 \%$ diabetic. At 3 weeks, descendents from ketotic diabetics mated to nonketotic diabetics were $16 \%$ trace glucosuric, $2 \%$ diabetic and by 2 months only $36 \%$ diabetic. - Animals from severely ketotic diabetic chinese hamsters are ideally suited for prediabetes research since they are predictable and rapidly become diabetic as proof of their earlier prediabetic state. Progeny from less severe diabetic parents are not predictable since only $59 \%$ developed diabetes and the incidence varied from litter to litter from the same parents. Further, nondiabetic parents have produced diabetic offspring. The data suggest that the inheritance of diabetes in chinese hamsters is complex since it cannot be explained by a single recessive gene.
\end{abstract}

Prévisibilité et développement du diabète dans la progéniture de hamsters chinois diabétiques

Résumé. Le glucose et les corps cétoniques urinaires de 253 hamsters nés entre janvier et septembre 1968 ont été mesurés toutes les deux semaines à partir de l'âge de 15 jours jusqu'en septembre 1969. Ces animaux proviennent de 67 nichées produites par 28 femellos mariées à 19 mâles de 7 lignées consanguines. - Tous les 46 hamsters provenant de parents diabétiques avec cétose sévère sont devenus diabétiques (continuellement $4+$ au Tes-Tape). 25 parmi ces 46 animaux ont développé une cétonurie (continuellement $4+$ au Ketostix). - Alors que $100 \%$ des animaux de parents diabétiques avec cétose sont devenus diabétiques en 8 mois, on trouve une incidence de diabète de $59 \%$ chez des animaux provenant de croisements entre animaux diabétiques cétosiques et noncétosiques; cette incidence est de $\mathbf{4 1} \%$ chez les animaux provenant de parents cétosiques diabétiques mais aveo des animaux ayant des traces de glycosurie; elle est de $24 \%$ chez ceux provenant de croisements d'animaux diabétiques cétosiques avec des non-diabétiques. - Le diabète apparaît plus tôt dans la progéniture d'animaux diabétiques avec cétose que chez celle issue d'animaux avec diabète léger. A l'âge de 3 semaines, parmi les petits de parents ayant un diabète cétosique, $26 \%$ montraient des traces de glycosurie, $26 \%$ étaient diabétiques et $2 \%$ étaient cétosiques. A l'âge de 2 mois, $85 \%$ sont devenus diabétiques. A l'âge de 3 semaines, les petits issus de mariages entre parents avec diabète cétosique et noncétosique ont présenté des traces de glycosurie dans $16 \%$ des cas et un diabète dans $2 \%$ des cas. Seulement $36 \%$ étaient diabétiques à l'âge de 2 mois. - Les animaux de hamsters chinois avec diabète cétosique sévère se prêtent de façon idéale à des recherches sur le prédiabète, parce que l'apparition de la maladie est prévisible et que, de plus, ces animaux deviennent rapidement diabétiques confirmant ainsi leur état prédiabétique antérieur. Chez la progéniture de parents ayant un diabète moins sévère, son apparition est imprévisible du fait que $59 \%$ seulement ont dévélopé un diabète et que la fréquence de la maladie varie de nichée à nichée issues de mêmes parents. Par ailleurs, on sait que des parents non-diabétiques ont eu des petits diabétiques. Ces données suggèrent que la transmission du diabète chez le hamster chinois est complexe puisqu'elle ne peut pas être expliquée par la présence d'un seul gène récessif.

Untersuchungen über die Voraussage und die Entwicklung des Diabetes bei Nachkommen diabetischer chinesischer Hamster

Zusammenfassung. 253 zwischen Januar und September geborene chinesische Hamster wurden ab dem 15. Lebenstag und bis September 1969 in zweiwöchigen Abständen auf das Vorliegen von Zucker und Ketonkörper im Urin untersucht. Es handelte sich um Tiere aus 67 Würfen von 28 Weibehen und 19 Männchen aus 7 verschiedenen Inzuchtlinien. Alle 46 Nachkommen schwer ketotisch diabetischer Eltern entwickelten einen Diabetes, der bei 25 Tieren auch von Ketonurie begleitet war. Innerhalb der ersten 8 Lebensmonate wurde ein Diabetes festgestellt bei $100 \%$ der Nachkommen ketotisch-diabetischer Eltern, bei $\mathbf{5 9} \%$ der Nachkommen eines ketotisch-diabetischen und eines nicht ketotischdiabetischen Elternteils, bei $41 \%$ der Nachkommen eines ketotischen und eines nur spurenweise glykosurischen Tieres und bei $24 \%$ der Nachkommen eines ketotisehen und eines nicht diabetischen Elternteils. Bei den Nachkommen ketotisch-diabetischer Eltern trat der Diabetes früher auf als bei denen von Eltern mit milderen Formen des Syndroms. 3 Wochen nach der Geburt zeigten $26 \%$ der Nachkommen ketotisch-diabetischer Eltern spurenweise Glykosurie, $26 \%$ waren diabetisch und $2 \%$ ketonurisch. Zwei Monate nach der Geburt waren $85 \%$ der Tiere diabetisch. Bei 3 Wochen alten Nachkommen eines ketotisch diabetischen und eines nicht ketotisch-diabetischen Elternteils waren die entsprechenden Werte $16 \%$ für spurenweise Glykosurie, 2\% für Diabetes, und im Alter von 2 Monaten waren nur 36\% der Tiere diabetisch. - Auf Grund dieser Ergebnisse wird geschlossen, daß sich Nachkommen ketotisch-diabetischer chinesischer Hamster geradezu ideal für die Untersuchung des prädiabetischen Syndroms eignen, da sie alle diabetisch werden und damit der endgültige Beweis für das Bestehen eines prädiabetischen Zustandes in kurzer Zeit erbracht werden kann. Bei Nachkommen weniger schwer diabetischer Eltern kann eine sichere Voraussage nicht gemacht werden, da nur 95\% der Tiere einen Diabetes entwickeln und auch dieser Prozentsatz von Wurf zu Wurf der gleichen Eltern stark schwanken kann. Da außerdem auch Nachkommen nichtdiabetischer Eltern Diabetes entwickeln können, scheint es daß die Heredität des diabetischen Syndroms des chinesischen Hamsters komplexer Natur ist und nicht auf Grund des Einflusses eines einzelnen rezessiven Gens erklärt werden kann. 
Key-words: Spontaneous diabetes, chinese hamster, cricetulus griseus, epidemiology, genetics of diabetes, conjugal diabetes in animals, diabetes in animals, inheritance of diabetes.
Although diabetes mellitus has been known for many years, little is known about the basic lesions which lead to the clinical signs of the disease. From the standpoint of therapeutics, it would be desirable to distinguish the individual destined to become diabetic from the normal. Then it might be possible to devise treatments to prevent or retard the development of the biochemical and morphological changes associated with diabetes.

Since diabetes is inherited $[11,14,13]$, it is reasonable to expect that the basic unknown defect might occur at conception provided the proper genotype is present. Unfortunately, it appears that the inheritance of diabetes in man is complex and difficult to predict $[13,8]$. Although considerable effort has been expended in attempts to define the initial lesions of prediabetes $[2,3]$, studies of prediabetes in man are difficult. Further, it will be difficult to find a prediabetic lesion in man since it may take years to change from a prediabetic to diabetic state and controlled genetic studies in man are impossible. Therefore, it is advantageous to use an animal model in which the time required to develop diabetes is short and in which controlled ge-
Nonketotic Diabetic: An animal whose urine had consistently tested $4+$ by Tes-Tape for a minimum of 2 months but had never been positive for ketones by Ketostix ${ }^{\circledR}$.

Ketotic Diabetic: An animal which consistently had a 4 - Tes-Tape result and in addition had ketonuria described as "large" by the Ketostix test for a minimum of 1 month.

All diabetics reported in this study have consistently had urine glucose tests of $4+$ by Tes-Tape for at least 10-12 months. Also, all ketotic animals were tested daily. All animals classified as ketotic breeders were consistently ketotic for at least 4 months.

Testing Procedures: At biweekly intervals, freshly expressed urine from each animal was tested for glucose with Tes-Tape from 15 days of age for a minimum of 15 months. Animals that tested $4+$ on Tes-Tape were also tested for urine ketones. All ketotic animals were tested daily.

It is recognized that a urine glucose test might miss an animal with slightly elevated nonfasting blood sugar. However, very few glucosuria-free hamsters have been found with nonfasting blood sugars greater than

Table 1. Incidence of diabetes in offspring of various diabetic matings

\begin{tabular}{|c|c|c|c|c|c|c|c|c|}
\hline \multirow[b]{2}{*}{ Type mating } & \multirow[b]{2}{*}{$\begin{array}{l}\text { No } \\
\text { offspring }\end{array}$} & \multirow[b]{2}{*}{$\begin{array}{l}\text { Minimum } \\
\text { months } \\
\text { tested }\end{array}$} & \multicolumn{3}{|c|}{ "Diabetics" (\%) } & \multicolumn{3}{|c|}{ Others $(\%)$} \\
\hline & & & Total & Ketotic & $\begin{array}{l}\text { Non- } \\
\text { ketotic }\end{array}$ & Total & $\begin{array}{l}\text { Trace } \\
\text { urine } \\
\text { glucose }\end{array}$ & $\begin{array}{l}\text { No } \\
\text { urine } \\
\text { glucose }\end{array}$ \\
\hline Ketotic $\times$ ketotic & 46 & 15 & 100 & 54 & 46 & 0 & 0 & 0 \\
\hline Ketotic $x$ non-ketotic diabetic & 90 & 17 & 59 & 16 & 43 & 41 & 32 & 9 \\
\hline Ketotic $\times$ trace glucosuria & 84 & 17 & 41 & 14 & 27 & 59 & 43 & 16 \\
\hline
\end{tabular}

netic studies can be done. Further, the diabetes of this animal model should be similar to diabetes of man. The chinese hamster is an animal which appears to be suitable since it inherits diabetes $[9,10]$ and the disease appears to be quite similar to diabetes in man [4].

\section{Methods}

Animals. Animals were selected for study from the Upjohn colony of chinese hamsters, which has been described previously [5]. This study was done on $\mathbf{2 5 3}$ chinese hamsters from 67 litters born from 28 females sired by 19 males and which are representative of the colony. Animals were classified by the following definitions.

Nondiabetic: An animal which had never shown a positive test for urine glucose by Tes-Tape ${ }^{\circledR}$ from birth for a minimum of 15 months.

Trace Glucosuric: An animal which had on occasion had a $1+$ rating on Tes-Tape; these animals are not considered diabetic.
$130 \mathrm{mg} \%$ while animals with $4+$ Tes-tape values have nonfasting blood sugars greater than $220 \mathrm{mg} \%$.

\section{Results}

The data presented in Table 1 show the incidence of diabetes in offspring from several types of matings. Forty-six animals have been produced by the mating of 2 ketotic parents. All of these 46 offspring have developed diabetes. Further, $54 \%$ of the 46 have become ketotic. When one parent was ketotic and the other was a nonketotic diabetic, only $59 \%$ of the 90 offspring became diabetic. Only $14 \%$ of this group became ketotic compared to $54 \%$ of the offspring from two ketotic parents. Also $32 \%$ of this group had a trace of urine sugar while $9 \%$ remained aglycosuric. When one parent was ketotic but the other had only trace glucosuria, the incidence of diabetes dropped further to $41 \%$ while higher percentages of trace-glucosurics and nondiabetics were found. The incidence of diabetes was further re- 
duced in offspring produced from a mating between a ketotic diabetic and a nondiabetic. In this case, diabetes dropped to only $24 \%$ and nondiabetics increased to $58 \%$. Also ketosis dropped to only $6 \%$ or 2 out of the 33 offspring which may not be significant. The differences in the incidence of diabetes in the offspring from the various matings were highly significant by chi square. No difference in incidence of diabetes was found with regard to which parent was the ketotic diabetic.

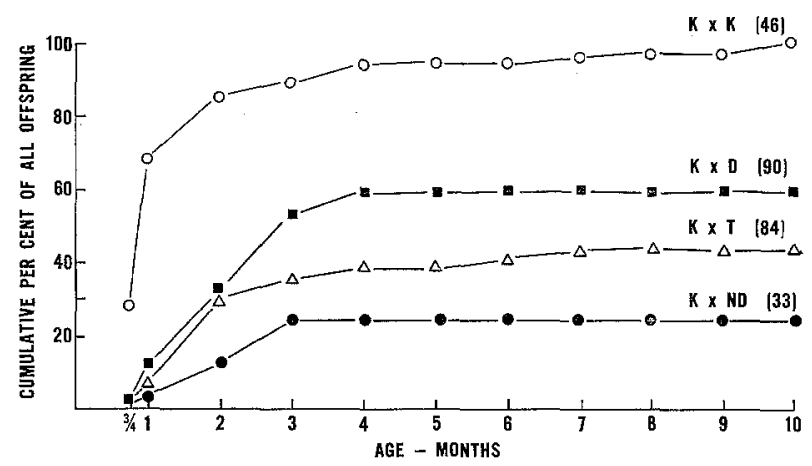

Fig. 1. Onset of diabetes in offspring from various matings of chinese hamsters.

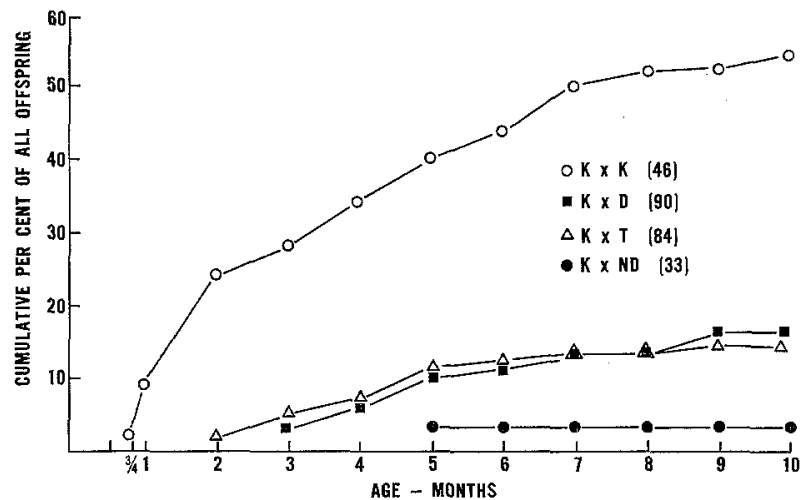

Fig. 2. Onset of ketosis in offspring from various matings

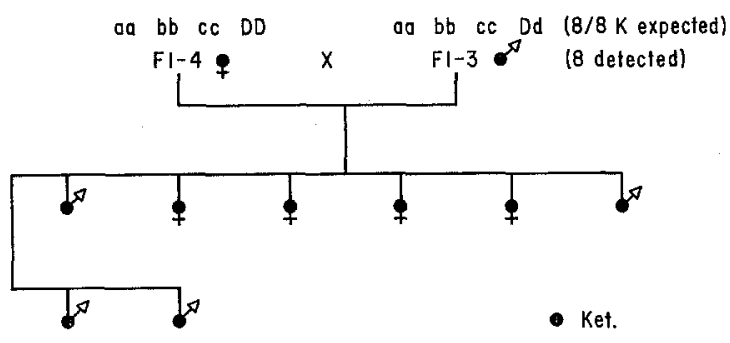

Fig. 3. Cross - ketotic $\times$ ketotic

The curves in Fig. 1 show the onset of diabetes of offspring from the various matings. In this case, the cumulative per cent of diabetic offspring includes both the ketotic and nonketotic diabetics. It appears that offspring from the ketotic matings develop diabetes faster than the other since $70 \%$ are already diabetic by 1 month of age. In the other 3 groups, most offspring become diabetic by 3 months of age. It is interesting to note that if animals were to become diabetic most of them developed glucosuria by 5 months of age regardless of their parentage.

The onset of ketosis was more rapid in offspring from the ketotic matings and the onset appears to progress in a linear fashion (Fig. 2). While $25 \%$ of the offspring from the ketotic matings were ketotic by 2 months of age, ketonuria was just beginning in the other offspring at 2 months. There was no difference in the onset or incidence of ketosis in offspring from ketotics mated to either diabetics or trace glucosurics. However, ketosis was quite rare in offspring of ketotic-nondiabetic matings since only 1 of the 33 offspring developed ketosis by 10 months of age.

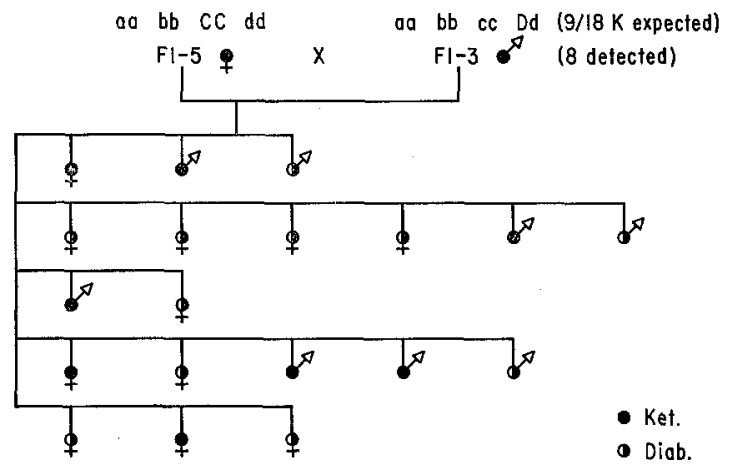

Fig. 4. Cross - ketotic $\times$ ketotic

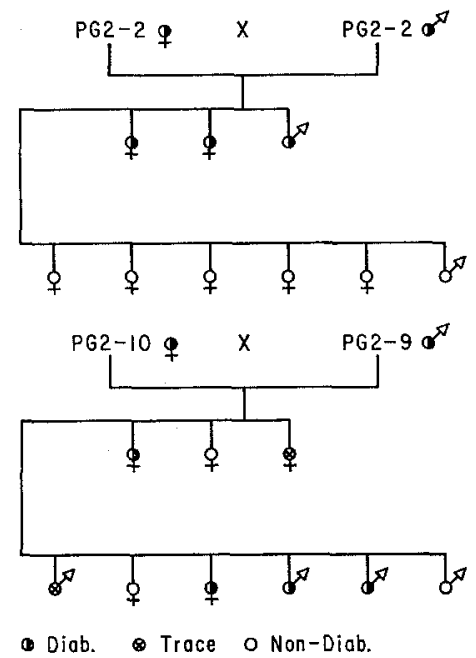

Fig. 5. Cross - diabetic $\times$ diabetic

Figs. 3 through 7 show individual offspring from various type matings and illustrate the variability of the results. The mating between two ketotic parents in Fig. 3 shows that all offspring developed ketosis. However, in Fig. 4, only 8 of 19 offspring of similar parents developed ketosis. Fig. 5 illustrates that a variety of offspring can be produced when two nonketotic diabetics are mated. The first litter of PG2-2-female mated to PG2-2-male was all diabetic while all offspring 
in the second litter were nondiabetic. In the second illustration, PG2-10-female produced diabetics, trace glucosurics and nondiabetics in both litters. When nondiabetics from inbred lines which produce diabetics are mated, they produce diabetic, trace glucosuric and nondiabetic offspring (Fig. 6). However, when nondiabetic hamsters from inbred lines which were established by selecting against diabetes are mated, they produce only nondiabetics (Fig. 7).

\section{Discussion}

Selection of the prediabetic individual for study of primary lesions of diabetes in man is very difficult. There are considerable data which show that children of two diabetic parents do not necessarily become dia-

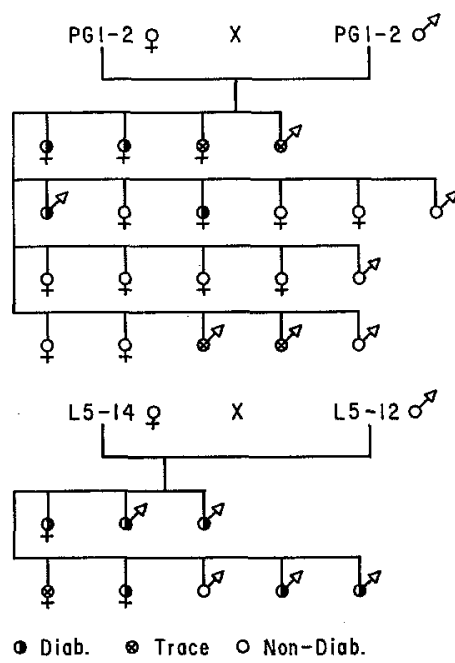

Fig. 6. Cross - nondiabetic $\times$ nondiabetic

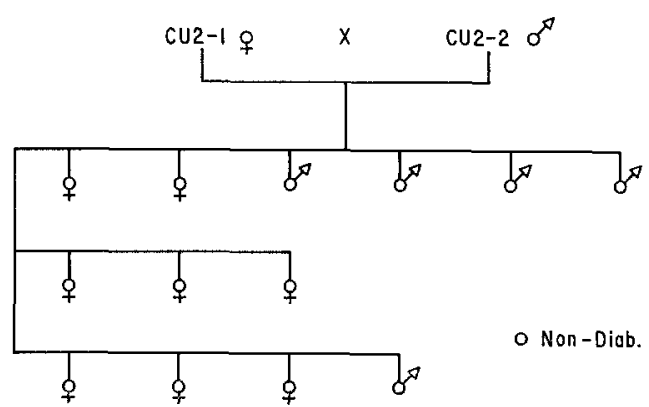

Fig. 7. Cross - nondiabetic $\times$ nondiabetic

betic [8]. The likelihood of both monozygous twins having diabetes is high but it is still not $100 \%[15,16$, $7,6]$. However, $100 \%$ of the offspring of two ketotic chinese hamsters do become diabetic rapidly. Therefore, these offspring must be prediabetic at birth and provide a very useful tool for research on prediabetes. Unlike man, they are readily identified by their lineage and can be used in terminal experiments for physiological, morphological and biochemical studies.
It is interesting to note that, regardless of parents, those hamsters which became diabetic, usually developed glucosuria by $3-5$ months of age. The observations concerning early, uniform onset of diabetes are in agreement with Schmidt's observations for the entire Upjohn chinese hamster colony [2].

In 1967, Butler proposed a four gene system for the inheritance of diabetes in the chinese hamster [1]. When any two of the four genes are homozygous recessive, a diabetic animal should result. The data presented in this paper are compatible with this hypothesis. Further, the data suggest that the hypothesis can be expanded to state that when any 3 of the 4 genes are homozygous recessive a ketotic animal will result. The validity of this hypothesis is supported by the data presented in Figs. 3 and 4. In Fig. 3 , if genes a, b and $c$ were homozygous recessive in the parents as illustrated then all offspring would have to be homozygous recessive and thus ketotic. This in fact is what happened since 8 out of the 8 offspring became ketotic. In the next example in Fig. 4, if the hypothesis is correct, all offspring should be diabetic since all offspring must bo homozygous recessive for genes a and b. All 18 offspring did become diabetic. Obviously all offspring are heterozygous for gene $c$ but half of them should be homozygous recessive for gene $d$ and therefore should be ketotic. Eight out of 18 did develop ketosis. Consequently, the observations match the predictions quite well and support Butler's four gene hypothesis. However, when both parents are not ketotic, it is difficult to predict which hamster will become diabetic. Since the results are rather unpredictable, they suggest a multifactorial pattern of inheritance. This suggests that if the inheritance of diabetes is similar in both man and the chinese hamster, then selection of human subjects as prediabetics should be done with care.

\section{References}

1. Butler, L.: The inheritance of diabetes in the chinese hamster. Diabetologia 3, 124-129 (1967).

2. Camerini-Davalos, R.A.: Biochemical and histological aspects of prediabetes, In "On the nature and treatment of diabetes." Ed. Liebel, B.J., Wrenshall, G.A., pp. 657-669. Amsterdam: Excerpta Medica Foundation 1965.

3. Conn, J.W., Fajans, S.S.: The prediabetic state. A concept of dynamic resistance to a genetic diabetogenic influence. Amer. J. Med. 31, 839-850 (1961).

4. Gerritsen, G.C., Dulin, W.E.: Characterization of diabetes in the chinese hamster. Diabetologia 3, $74-84$ (1967).

5. - - Serum proteins of chinese hamsters and response of diabetics to tolbutamide and insulin. Diabetes 15, $331-335$ (1966).

6. Harvald, B., Hauge, M.: Selection in diabetes in modern society. Acta med. scand. 173, 459-465 (1963).

7. Joslin, E.P., Root, H.F., White, P., Marble, A.: The treatment of diabetes mellitus. 10th Ed., p. 348. London: Henry Kingston 1959.

8. Malins, J.: Clinical diabetes mellitus, pp. $6-13$. London: Eyre \& Spottiswoode 1968. 
9. Meier, H., Yerganian, G.E.: Spontaneous hereditary diabetes mellitus in chinese hamster (Cricetulus griseus). I. Pathological findings. Proc. Soc. exp. Biol. 100, $810-815(1959)$.

10. - - Spontaneous diabetes mellitus in the chinese hamster (Cricetulus griseus). TI. Findings in the offspring of diabetic parents. Diabetes 10, 12-21 (1961).

11. Pincus, G., White, P.: On the inheritance of diabetes mellitus. I. An analysis of 675 family histories. Amer. J. med. Sci. 186, 1-14 (1933).

12. Schmidt, F.L., Leslie, L.G., Schultz, J.R., Gerritsen, G.C.: Epidemiological studies on the chinese hamster. Diabetologia. In this issue.
13. Simpson, N.E.: Multifactorial inheritance. A possible hypothesis for diabetes. Diabetes 13, 462-471 (1964). 14. Steinberg, A.G.: The genetics of diabetes: a review. Ann. N. Y. Acad. Sci. 82, $197-207$ (1959).

15. Then-Berg, H. : Die Erbbiologie des Diabetes Mellitus. Arch. Rass. u. Ges. Biol. 52, 289 (1938).

16. Umber, F.R.: Erblichkeit. Rassenhygiene und Bevölkerungspolitik: Diabetes und Erbanlage. Münch. med. Wschr. 11, 1479 (1939).

Dr. G.C. Gerritsen

Diabetes Research

The Upjohn Company

Kalamazoo, Michigan, USA 